\section{THE IMAGE OF CHINA IN THE CORRESPONDENCE OF CATHERINE II}

Summary: In 1762, Catherine II (1729-1796), Catherine Grand, as Voltaire called her, an extraordinary woman who was destined to undergo many reforms and establish Russia's place in the world, ascended to the Russian throne. Her reign coincided with the reign of Emperor Qianlong (1711-1799), one of the most enlightened monarchs in Chinese history; during his time, the empire achieved many military victories and brilliant achievements in the arts.

By the time of Catherine's accession to the throne, relations between the two countries were very strained. Meanwhile, the age of Enlightenment, the century of the ardour for the philosophy and art of China, began in Europe. On the one hand, Catherine was influenced by the ideas of the West; on the other hand, she constantly had to regulate conflicts on the Russian-Chinese border, the reason for which was most often the question of extraditing Mongols and Dzungars to the Chinese who were fleeing within Russia. The purpose of this article is to determine what image of China the Russian empress formed and how she spoke about this country in her correspond

The reign of Catherine II (1762-1796) coincided with the era of Enlightenment in Europe and the reign of Emperor Qianlong in China (1736-1795). This reign was marked by the adoption of important political, legislative and administrative measures, achievements in the field of science, literature and art, a number of military celebrations, a constant increase in the strength of the popular forces and the state glory of Russia.

It is known that as a child, Catherine received minimal primary education. "Well," she said once. "Maid Kardel could not have taught me better. She was an old Frenchwoman and educated me enough to be married to one of our neighbours" [2, p.XXIII] However, like Peter I and most of the great people Catherine strove for self-improvement. She soon
Catherine II wrote a lot. To do this, first, it is necessary stand her interests and habits. To understand what issues she had to resolve, one also needs to know the state of Russian-Chinese relations in the second half of the 18th century. Finally, the article gives a general description of Catherine II's correspondence with various high-ranking persons, among whom Jean d'Alembert, Diderot, Voltaire, Friedrich Melchior Grimm (Franco-German publicist, artist and literary critic), Swiss scientist and philosopher Johann Georg Ritter von Zimmermann, Madame Geoffrin and Madame Bielke can be named. The letters she received very often contained diplomatic news, dynastic problems, court gossip; her answers were, for the most part, semi-official journal notes. It is noteworthy that de spite the extensive correspondence conducted by Catherine the Great, she practically did not touch upon the issues of China, except for letters to Voltaire, who, as you know, admired China and tried to learn more about from the words of the empress.

Keywords: China, Catherine II, Qianlong, Enlightenment Voltaire, correspondence

made up for the shortcomings of her upbringing becoming on a par with the most educated people of her century. After the wedding, she, according to her, did nothing but read. "Never without a book and never without grief but always without entertainment," this is how Catherine outlined her pastime at that time $[7$, p.530]. Soon she became briefly familiar with the works of modern and ancient philosophers and politicians.

Having fallen in love with her second homeland with all her heart, Catherine studied its language history, and her people's way of Ife. She made a significant contribution to Russian historiography. "The science of Russian history begins with Catherine II" [2, p. VIII]. Many Russian chronicles were first published during her reign, making it possible

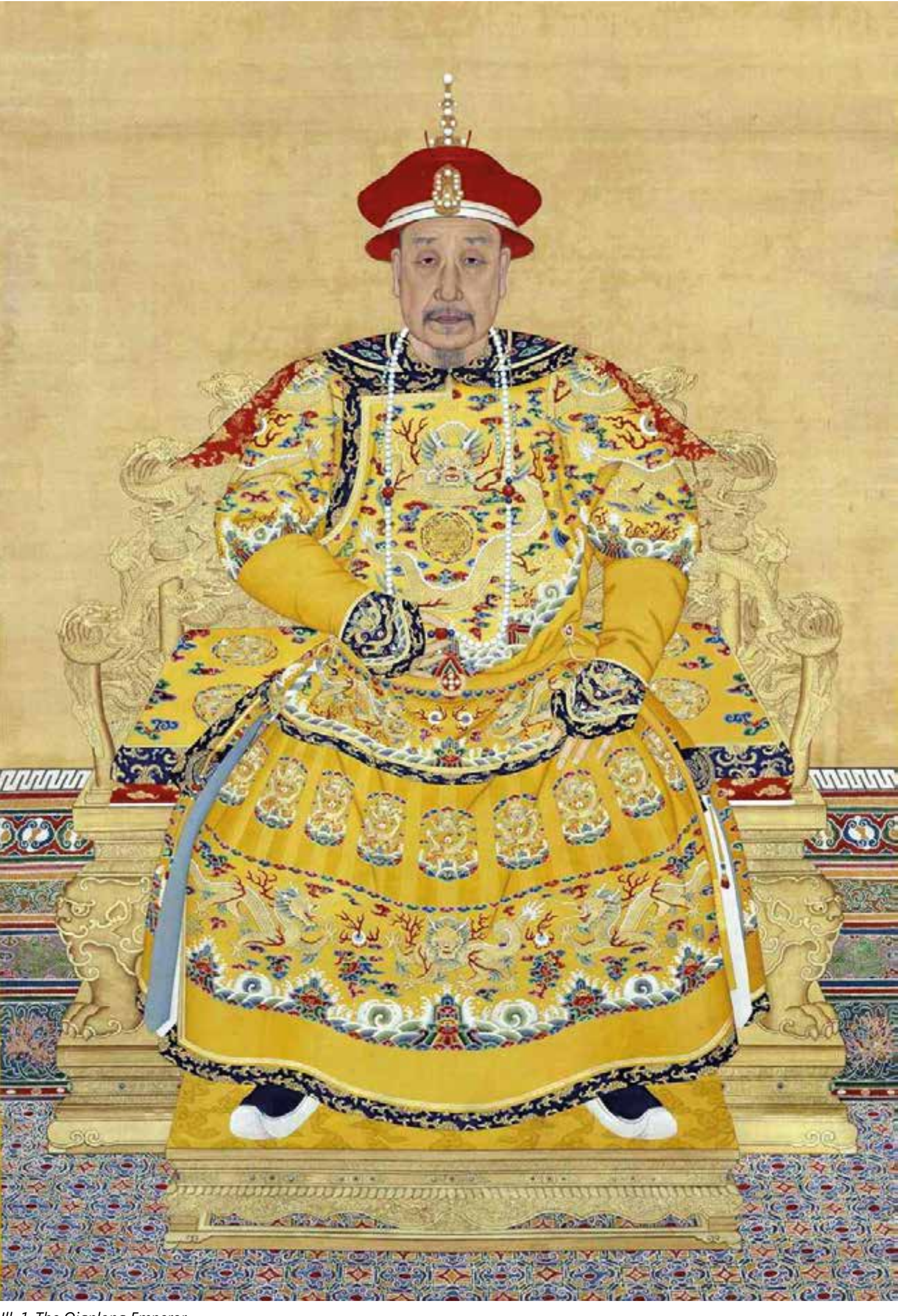

II. 1. The Qianlong Emperor 
for scientists to compile Russian history. Catherine herself was among the Russian historians. While be ing the Grand Duchess, she devoted several hours every day to reading history, making extracts and notes later included in her Notes on Russian Histo$r y$, which appeared first in the Sobesednik, and then were published in a special edition. "The Empres explains their publishing, on the one hand, by the fact that every nation needs to know its own history and geography more than foreign, and, on the other hand, that 'they are not composed for young people at a time when books are published in foreign languages under the name Russian History, which can be called rather biased creations since each page serves as evidence of what hatred it is written with each circumstance is not only presented in a perverse form, but a malicious talk is added freely to them'" $[2$, p.X]. This proves that Catherine II protected the honour of Russia even in the field of science.

Being the most educated woman of her time, the Empress could not ignore the ideas of Enlightenment, among which was the idea of an "enlightened monarch". "Like the French feudal lords, Catherine II and her courtiers were looking for a substantiation of the nature of despotic power in the way of life, laws, philosophy and history of China. $<\ldots . .>$ No wonder Catherine, by a special decree, commanded to translate the Criminal Code of the Qing, where the one-man rule of government was glorified, and the privileges of the Manchu nobility were legalized" [14, p.67]. "Catherine is reading Essai sur les Moeurs e Esprit des Nations, Le Siècle de Louis XIV, Dictionnaire Philosophique de la Chine. And the play L'Orpheline de la Chine (1755) was even supposed to be staged in the court Hermitage Theater by analogy with its staging in front of the Chinese Pavilion in the Sanssouci Park in Potsdam. By the highest order, Alexei Leontiev, one of the first European sinologists, translated from the Chinese language in the 1770s. Moreover, most of the translations "were paid by the Cabinet" [11, p.73]. Interest in China was fueled largely by communication with Voltaire, who admired China and used Chinese history for sharp philosophical polemics. Voltaire spoke most fully about China in An Experience of Morals, Philosophical Dictionary, Papers of Jean Neslier and an article "On the Expulsion of the Jesuits". "Voltaire notes that if a philosopher wants to talk about the events of the world, he must first cast his eyes to the east 'the cradle of all arts, to which the West is wholly obliged'" [1, p.317]. Catherine followed Voltaire's in- structions. She not only studied the philosophy and literature of China but also began collecting objects of Chinese art. In Oranienbaum, a Chinese Palace appeared, in Tsarskoye Selo - Chinese buildings, and in the Winter Palace - Chinese rooms.

In terms of Catherine's foreign policy, the precarousness and volatility that had characterised Russian politics before her reign gave way to decisive action. "Instead of friendship with all the powers, during 34 years of her reign, she ruined friendship between Russia and almost all the major states of Western Europe and brought one of the bloodiest reigns to our history, waged six wars in Europe and before her death, was preparing for the seventh with revolutionary France" [7, p.563].

Not everything was calm in neighbouring China either. "From 1685 to 1792 , the Manchu emperor fought 11 wars that lasted more than 50 years in total. From 1721 to 1795,12 major uprisings took place in China, mainly raised by national minorities. It took almost 30 years to suppress them. Externa and internal military actions often took place simultaneously" [12, p.145]

Having come to power, Catherine II was engaged in settlement of relations with China with special at tention. Until the mid-50s of the 18th century, friendly ties remained between Beijing and St. Petersburg. However, the situation changed dramatically after the conquest of Dzungaria, the flight of a part of the Oirats, and then of the sovereign prince of the Oirat Khanate, Amursan, to the Russian borders, after the transition of individual Mongolian principalities to the Russian side [12, p.144]. The main reason for the difficulties that arose was mainly the issue of handing over the Mongols and Dzungars, who were fleeing within Russia, to the Chinese. On the other hand, the Russian government could not become an accomplice to the atrocities awaiting defectors in China. As a result, the Chinese government not only did not allow Russian caravans to cross the borde but even strictly forbade its subjects to maintain relations with the Russians [10, pp.28-29].

In 1762, the Empress sent Captain I. Kropotov to notify Emperor Qianlong of her accession to th throne and settle border issues. "The Bogdykhan received the Russian ambassador; however, they treated him so dryly that he could not achieve anything to restore trade" $[10$, p.30].

Relations between Russia and China were not easy. For example, F. Martens believes that "from the very beginning of Russia's relations with China, the Chines had confidence in them. They have always strictly distinguished Russians from subjects of other European states, whom they call foreigners and even 'overseas devils'" [10, p.2]. However, events showed that the attitude towards the Russians was not always trusting. According to Martens, the reason for this was "the unfortunate consequence of the treatment that the Middle Empire was subjected to by other civilised powers, and the unjust wars waged against it" $[10, p .73]$. The emergence of troubles was also facilitated by the fact that Russia was mentioned as a vassal state to the Bogdykhan in Chinese works on geography $[10$, p.7]. "Such a view was instilled in the Bogdykhans and was reflected when they received Russian envoys. For a long time the Bogdykhans sincerely saw in them only those sent from their subservient people and demanded worship and tribute humiliating for the Russian dignity. Those Russian people sent to establish trade relations with China or on border affairs who did not agree to humiliation did not achieve the goal of their mission either" $[8$, p.76]. This attitude towards Russia as a subservient people was reflected in Russian-Chinese correspondence. "The Russian side, in a contractual way confirming its readiness to correspond with the Lifan Yuan (the Chamber for Vassal (!) Territories), as it were, recognised itself as a 'vassal' of the Qing Empire. However, on the other hand, from now on, with this appointment', 'many contradictions that arose during the correspondence of the tsars were removed therefore, the process of Russia achieving its goals was facilitated"' [9, p.107].

Since 1763, relations between Russia and Chin had taken an even worse turn. In 1764, all official correspondence with the Chinese government was terminated since Empress Catherine II could not respond to the daring notes of the Lifan Yuan without losing her dignity [10, p.30]. In August 1764, ag gravated relations with the Chinese and because of the "threatening" situation adopted by the Chinese forced Catherine to draw up an emergency conference with Prince Golitsyn, Counts Panin, Chernyshev, Minikh, Olsufiev, Neplyuev and Vilboa in August 1764 One of its aims was to send a military expedition to the Amur $[15$, p.60]. In the same 1764, she established a committee of competent persons to study the terms of trade with China. Based on its results, it was decided to abolish state trade with China, hand it over to Russian merchants, and transform the entire administration of Siberia to improve relations with the Heavenly empire [10, p.29].
From 1762 to 1768 , bargaining ceased and resumed incessantly until, in 1768, Captain Kropotov was again sent to Kyakhta to resolve disputes over border and trade matters. "After a long debate, the plenipotentiaries signed a separate act or addition to the treatise of 1727 on October 18, 1768" [10, p.30]. Since 1768 , after seven years of strife, seven years of peace came - the longest peace since 1719 [15, p.62]. The next break in relations with the Chinese occurred in 1778 (lasted until April 2, 1780) ove some Olot, Russian subjects who plundered Rus sian merchants and fled to China [15, p.63]. In 1785, a new break occurred, which lasted until April 24 1792. Several robbers of Russian citizenship, led by Uladzai (Ulagai), were caught at the border. The Chinese demanded their execution at the crime scene and the Irkutsk governor only exiled them. "As a result of this, in 1785, the tribunal complained that the governor willfully exiled them to distant exile after only beating Ulagai and others who had previously staggered" [15, p.63]

Against the background of all these events, it was interesting to know how the Russian empres responded about China in her correspondence with foreign correspondents since, as it is known, she wrote a lot. She once remarked to her secretary Gribovsky, "you cannot even live one day without writing" [2, p.XIII]. The reason for such literary activity was not only a property of her character but also the influence of the spirit of the time when imitation of the great minds of that century was adopted. It is when the extensive correspondence began. The empress corresponded first with D'Alembert Diderot and Voltaire, then with half-German, halfFrench Grimm, then with Hanoverian scholar Zimmermann, with Madame Geoffrin, who lived in Paris and had a literary salon, which was considered a literary centre and the supreme aesthetic court, Mad ame Bielke, who during Catherine's childhood was close to her mother and lived in Hamburg. "These relations had a multifaceted purpose: on the on hand, Catherine wanted to constantly know about everything that happened in the West and what was said about her; on the other hand, knowing the extensive connections of these persons, as well as their authority and influence on public opinion she wished, with her letters to them, to disseminate true, or at least which agreed with her views, information about Russian affairs, to refute slander and false talk, which were incessantly dismissed by the enemies of Russia" [2, p.XIV] 
The letters she received very often contained political messages; her answers mainly were semi-official journal notes: there were bulletins about campaigns, and militant articles, and even "real manifestos, as in a letter dated January 21,1791 , written to Zimmermann but intended for the Berlin court, which had to be pacified, giving it at the same time advice no to interfere in Turkish affairs. Many of the notes to Voltaire were intended to shake the position of the Duke of Choiseul. Catherine herself once confessed that to Khrapovitsky" [5, pp.385-386]

When familiarising with her correspondence with various persons, which amounted to five volumes published by the Imperial Russian Historical Society, it is striking how much she wrote about European affairs and practically nothing about relations with China, which, in general, should be regarded as a positive phenomenon. Voltaire and then Prince Charles de Ligne were her correspondents with whom she talked about China. Acquaintance with Voltaire's works began soon after she arrived in Russia, when she, on the advice of Prussian envoy Mardefeld, refused to spend idle time and started reading $[2, p . X$ VI]. "Since 1746, since the time that I have My own time, I feel your great favour. Before this era, I had not read any books other than novels; however, by chance, your works fell into my hands. Since that time, they constitute My usual reading, and I have not looked for other books, except those that are so well written, and in which there are just as many useful things," [13, pp.4-5] she wrote in her first letter to Voltaire.

In the correspondence between Catherine II and Voltaire, which lasted from 1763 to 1777 - until Voltaire's death, many questions about Russian domestic and foreign policy were raised. Polish historian K. Valishevsky (1849-1935) has interesting lines. "She dreamed of building a Ferney Palace in Tsarskoye Selo, reproducing a completely external and internal view of the famous dwelling - a room where the philosopher thought and wrote, even the landscape on which his gaze rested. At the same time she would never agree to publish her correspondence with him: her letters were too badly written his - too flattering for her and disrespectful for other rulers. And since this correspondence was no approved by many, and the too suspicious highe clergy saw in it almost a scandal, she simply began to deny it. She could not forbid Voltaire to write to her - so many people wrote to her! However, she did not answer him; she rejected all his attempts to involve her in a correspondence that would be unworthy of the Empress of All Russia" [5, p.213].

"In her frank conversations with Grimm, she found that 'their tone is very ordinary'" $[5, p .391]$. This by no means characterises Catherine as an unwise ruler. As already mentioned, Catherine was very well-read and protected the interests of Russia in everything "In her reception of foreign ambassadors, in her relations with anyone, every word, her every step showed an extraordinary tact and skill to produce the desired impression unmistakably. Catherine was as subtle a diplomat as a skilful administrator" [2, p.XXIV]. Catherine tried to follow modern fashion. "Fashion was to treat everything casually, ironically, to make ridicule even in the discussion of the most serious issues. Voltaire taught his pupil all this; she was delighted with this direction and applied it at random, like a capricious, courageous woman, paying little attention to rules and decency" [5, p.391].

The relationship between an ambitious, politically powerful woman and a highly gifted, universally educated philosopher, one of the greatest authorities in French Enlightenment, was mutually beneficial. Catherine realised that letters to Voltaire would become known to his friends and treated them like messages to the intelligentsia of Europe. "For Voltaire, what could be more flattering than having another royal apprentice in the person of the reigning monarch? He addressed her as 'Semiramis of the North', 'Saint Catherine' and 'Our Lady of St. Petersburg'. In response, she showered him with sable furs and jewelled snuffboxes and sent diamonds to Madame Denis. However, it was a relationship that flourished at a distance; despite the intimacy of their correspondence, the Empress and the venerable elder never met" [16, pp.335-336].

As Valishevsky notes, the empress's letters can be divided into three categories: letters written by her, composed by her and written by her order. The former are the rarest $[5, p .386]$. Letters to Voltaire in his opinion, were almost all written to order and were a kind of literary works. "I write with my own hand only to those people who, I believe, love me and whom I value; it is impossible for me to pursue a wit, a selective presentation", she wrote to the Duke de Ligne, "therefore, I do not write at all for this to be published, and nothing seems to me as vulgar as what I wrote when I come across it in print" $[4$, p.96]. She copied letters to the Ferney patriarch with her hand, retaining her characterstic manner of writing: "a well-known familiarity playful good nature and sincerity, even originality of thought and expression", skillfully handled by the suppliers of French or Russian prose - Shuvalov, Kozitsky or Khrapovitsky, who in turn served as secretaries to the empress [5, p.387].

As it is known, in his work Experiments on Mor $a l s$, Voltaire initially, before adding the introductory part, began his presentation of world history from the East - from China, "where civilisation firs emerged, while the West was in complete barbarism" [6, pp.173-174]. In contrast to ancient Israel and the states of modern times, for Voltaire, it was a country of acquired wisdom, justice and in ner peace. "Although the Chinese have not excelled in the sciences, they are the world's first people in morality and culture (police). It is explained, according to Voltaire, by the fact that the head of the state is a sage - an emperor, surrounded by philosophers - Mandarines. They profess Confucianism which represents a purely philosophical religion deism. The masses of the people, it is true, will become stiff with gross religious prejudices; however, the emperor and the Mandarins wisely use opportunities to undermine the people's lower beliefs and cults. Starting from sentimental, idealised descriptions of travellers and missionaries, Voltaire created a moralising fable and a lesson to Europeans from Chinese history" [6, p.174]. It is natural to assume that when he corresponded with Catherine, Voltaire could not help but inquire about Russia's neighbour, China, in which he had such an interest.

First the philosopher tried to start a conversation about the literary talents of the Chinese emperors. Thus, in a letter dated May 26, 1767, Voltaire wrote: "Your neighbour, the Chinese Emperor, Kamgi, asked a Missionary if it was possible to write poetry in European languages? He doubted it" [13, p.25] However, Catherine decided to leave this remark unanswered. Three years later, in a letter dated November 20, 1770, Voltaire again tried to touch upon the topic of China: "You have two neighbours who compose poetry, namely the King of Prussia and the Emperor of China. Frederick has already composed to you in praise, I have and now expect it from KienLong" [13, p.133]. And again, there was no answe to these lines. In the following letter, dated November 26, Voltaire again mentioned the bogdykhan "Long live the Chinese Emperor! He composes poetry and lives in peace with the whole world!" [13, p.134] And again silence in response. In the next letter, dated December 22, 1770, Voltaire already wrote impatiently: "Most Merciful Empress! My passion is becoming somewhat unhappy. I have no news of either Your Imperial Majesty or my enemy Mustafa. All that I can still do is to inform you of my boring correspondence with the Chinese Emperor, your neighbour" [13, p.140]

As mentioned above, the years from 1762 to 1770 were filled with the solution of numerous troubles that arose on the Russian-Chinese border, about which Catherine preferred not to speak. And finally, in a letter dated December 23, 1770 she wrote about China: "Ah, My Lord! You have praised China so much that I no longer dare not approve of the poems composed by that country's Sovereign. However, in the affairs that I have with this Government, I could present such evidence, which would greatly diminish the generally accepted good opinion of their enlightenment and make one think of them as gross ignorant; but why should one offend their neighbour? I, imposing silence on myself, marvel without any contradiction at the narratives sent from the confessors who are there. What is more, it must be said that I am dealing with the rule of the Tatars, who conquered China, and not with the natural Chinese [13, p.143]

Then, in her next letter dated January 12/23, 1771 Catherine continued: "It seems to me that you can be satisfied with the year 1770 and that you still do not have a reason to praise My neighbour, $\mathrm{Ch}$ nese Emperor, despite the poems and your revived love for him (please do not get angry), I do not find meaning in it. You say that jealousy alone makes $M$ speak there; far from it; I will not trade my Roman nose for his flat face; nor do I envy his talent for writing bad poetry; I only like to read yours alone. The epistle written to My rival is beautiful. Immediately upon its receipt, I showed it to Prussian Prince Henry, and he was equally pleased with it. If fate pleases that I, in the judgment of you, have a rival then I pray to the Most Holy Mary that this is someone else, not the Chinese Sovereign; for I am angry with him" [13, p.148].

Then, apparently, relations with China becam better as the empress wrote calmer two months later (letter dated March 3/14, 1771): "Since my neighbour, Chinese Sovereign, eliminated some unjust oppression, his subjects entered into trade with me. In the first four months since this bargaining opened, they have exchanged goods for three million rubles. My neighbour's factories are busy making wallpaper 
for me, and he asks Me to deliver him sheep and bread" [13, p.156].

In the following letter (dated March 5/15, 1771), Catherine gave a more detailed description of relations with China: "You want me to tell you something about the ignorance and rudeness of the Chinese, which I mentioned in one of my letters. We are neighbours, you know that. Our borders on both sides are inhabited by Tatars and idolaters who feed on cattle. These peoples are overly prone to plunder. They kidnap each other herds, and even people (often out of the same vengeance). The resulting quarrels were stopped by the commissars sent to the borders. The Chinese are such great snitches that it is as difficult to resolve a minor problem with them it is to drink the sea. It happened more than once that being satisfied in everything, they demanded bones after the dead not to give them any honour but to abuse them. For ten years, such stinginess served them as an excuse to suppress trade; I say with the pretext that the real reason was that his Chinese Majesty gave the bargaining with Russia to one of his Ministers in Monopoly. The Chinese and the Russians were equally unhappy, and as it is challenging to interrupt any exchange bargaining, both peoples exchanged their goods in those places where no customs outposts had been established, preferring their needs to dangers. When we gave them detailed information about the state of mutual relations, in return, we received a great heap of papers, written so randomly that after reading them from beginning to end, we could only see ignorance and rudeness instead of meaning and politeness. From us, they were told that such words were not suitable for us as it is considered offensive in Europe and Asia. I sense your objection. You will say that the Tatars, who seized the Chinese State are much worse than the ancient Chinese; I agree! However, it will remain indisputable that the winners did not learn politeness from the defeated, and these, in the end, will be forced to submit to the prevailing customs" $[13, \mathrm{p} .160]$.

It is what little the Empress allowed herself to say about China. In addition to discussing Emperor Qianlong's poems and trade with China, anothe topic of correspondence was the possibility, through Russian merchants, to sell watches produced by Voltaire's factory to China. "To help the people in his village, he built a watch factory and then persuaded all his friends in Europe to buy their products $<$...> By 1777 , this once small, impoverished village of 49 people turned into a prosperous town of 1200 people" [16, p.334].

Catherine II was no exception - Voltaire addressed her with a lengthy speech, very reminiscent of an offer to place an order with him. "It seems to me, if your Nivkh Tatar-Chinese were quick-witted they could buy inexpensive watches and sell them in their State with great profits. The people of $\mathrm{Ge}-$ neva have an Office in Canton and receive a substantial profit there. Is it possible to establish one on your border as well? My colony would make silver watches at the cost of 12 to 15 rubles and gold watches priced from 50 to 40 rubles. Moreover, it would undertake to exhibit them for 200,000 rubles every year, if necessary. However, it seems to me that due to the distrust and suspicion of the Chinese, it is hardly possible to enter into a big bargain with them, requiring compliance and frankness" [13, p.167].

The empress did not refuse and bought watches for three to four thousand rubles. However, Voltaire soon sent her a second batch of watches, hastening to apologise: "It happened from the too great zeal of the 'colonists'"- it is not his, but their fault. "However, the bill is only 39,238 French livres, which is half the price in London, Paris and even Geneva. All benefits are provided upon payment." - "Well", answered Semiramis, "but this is the last time". She sent 39,238 livres, along with a bulletin about the latest exploits of the Russian troops, about which the person who is most read in the whole world should notify Europe" [5, p.202].

Further, in a letter dated May 24 / June 4, 1771 Catherine expressed her consent to the proposal for the sale of watches. "I think it would be possible to ship their products to China; however, it would require some educated merchant who would know the customs of trade with Kyakhta - the place bordering Russia where this trade is made. $<\ldots>$ At my command, the customs tariff for trade with China is being revised to alleviate it in order to facilitate import and export. The prices that you set are so moderate that the products of your production can have great sales" [2, p.103].

Voltaire, apparently, was inspired by these lines since, in one of his letters, he again tried to offer Catherine not watches but a wall clock. In a letter dated December 3/14, 1771, Catherine suggested contacting "some local office where there are Geneva residents who can easily find a means to deliver clocks to the Chinese border" $[2$, p.199].
The last letter to Voltaire was written on December 4 / November 23, 1777; on May 30, 1778, the philosopher passed away. For 14 years of correspondence, Voltaire and Catherine never met.

Since that time, in her letters, Catherine had not touched on Chinese affairs. Only sometimes, in the correspondence with Prince de Ligne, which began in 1781, she casually talked about the Chinese emperor. Thus, in a letter to Prince de Ligne about the memory he left about himself in Russia (July 11, 1782), she wrote: "Neither my dear friend, the Byzantine Emperor, nor my good neighbour, the Emperor of China, is unable to prevent me from reading your letters, infinitely more pleasant than their letters despite their high rank in the almanacks" [3, p.210]. Or, as in a letter about the states neighbouring Russia (November 16, 1790), she reported: "The Beijing newspaper says that my Chinese neighbour with small eyes, about whom you speak so honourably, observes with true approximate accuracy all the countless rituals, to which he is subordinate" $[4, p .125]$. It is the little that the empress allowed herself to say about China in her correspondence with the prince.

Summing up the above, we can say that Catherine's views on China were greatly influenced by Voltaire, with whose works she was well acquainted and with whom she had corresponded for fourteen years. Under Catherine, many translated materials on the topic of philosophy, state structure, and customs of China appeared in Russian periodicals. However, reading the papers from the Chinese government, she realised that everything that Voltair admired was somewhat related to the ancient Chinese culture, the bearer of which the Han nationality was. Also, she had to deal with the Manchus who seized power. They came from the northeast and their customs and traditions were somewhat different. The situation on the Russian-Chinese border was turbulent. During the reign of Empress Catherine II (1762-1796), trade relations with China ceased three times, namely in 1762 for six years, was challenging to correspond with the Chinese court. Nevertheless, the empress preferred not to expand on relations with China in letters to he numerous European correspondents, which she wrote almost every day. The exception was letters to Voltaire, to whose comments she had to answer and which, in the opinion of Catherine herself, were poorly written. This restraint in correspondence can only be regarded as a positive phenomenon indicating that Catherine protected state interests concerning China, preferring not to interfere with Western states in relations with her eastern neighbour. 
1. Alekseev, M.P. 1987. Pushkin i mirovaya literatura.

2. Bumagi imperatritsy Ekateriny II, khranyashchiesya v gosudarstvennom arkhive Ministerstva inostrannykh del. - Vol. 3 (1762-1774), St. Petersburg: Tipografiya Imperatorskoi akademii nauk, 1874.

3. Bumagi imperatritsy Ekateriny II, khranyashchiesya v gosudarstvennom arkhive Ministerstva inostrannykh del._- Vol. 4 (1774-1788). Sbornik imperatorskogo russkogo istoricheskogo obshchestva. - Vol. 27, St. Petersburg: Tipografiya Imperatorskoi akademii nauk, 1880.

4. Bumagi imperatritsy Ekateriny II, khranyashchiesya v gosudarstvennom arkhive Ministerstva inostrannykh del._ Vol. 5 (1789-1796). Sbornik imperatorskogo russkogo istoricheskogo obshchestva, Vol. 42, St. Petersburg: Tipografiya Imperatorskoi akademii nauk, 1885.

5. Valishevskii, K.F. 1911. Vokrug trona: Ekaterina II, Moscow.

6. Vol'ter: Stat'i i materialy / Pod red. akad. V. P. Volgina; Akad. nauk SSSR, Moskva; Leningrad: 2-ya tip. Izdatel'stva Akademii nauk SSSR, 1948.

7. Klyuchevskii, V.O. 2003. Russkaya istoriya. Polnyi kurs lektsii v 2-kh knigakh. - Kniga 2, Posleslovie, kommentarii A. F. Smirnova, Moscow.

8. Kuropatkin, A.N. 1913. Russko-kitaiskii vopros. - St. Petersburg: Tip. Tovarishchestva A.S. Suvorova «Novoe Vremya».
9. Lapin, P.A. 2012. "Rossiisko-kitaiskaya mezhgosudarstvennaya perepiska kak vid vneshnepoliticheskoi deyatel'nosti: kitaiskii aspekt (pervaya polovina XVIIvtoraya polovina XIX v.)", Rossiya i Kitai: problemy strategicheskogo vzaimodeistviya: sbornik Vostochnogo tsentra, no. 12, pp. 106-114.

0. Martens, F.F. 1881. Rossiya i Kitai, St. Petersburg: Tip. I. Gabermana.

11. Men'shikova, M. 2016. "Zdes' «vse dyshalo ambrozie Azii»", Voobrazhaemyi Vostok: Kitai «po-russki». XVIIInachalo XX veka, Moscow, pp. 66-73.

2. Nepomnin, O.E. 2005. Istoriya Kitaya: Epokha Tsin XVIII-nachalo XX veka.-Moscow.

3. Perepiska rossiiskoi imperatritsy Ekateriny II i gospodina Vol'tera, prodolzhavshayasya s 1763 po 1778 god Perevel s frantsuzskogo Ivan Fabiyan; S portretom imperatritsy i Vol'tera, Moscow: V vol'noi tipografii Gariya i Kompanii, 1803.

14. Skachkov, P.E. 1977. Ocherki istorii russkogo kitaevedeniya, Moscow: Izdatel'stvo «Nauka», Glavnaya redaktsiya vostochnoi literatrury.

15. Trusevich Kh. 1882. Posol'skie i torgovye snosheniya Rossii s Kitaem (do XIX veka), Moscow: Tipografiya G. Malinskogo.

6. Robert, K. 2012. Massie. Catherine the Great: Portrait of a Woman, New York: Random House Trade Paperbacks.

Наталья Геннадьевна Сураева

Кандидат искусствоведения

Институт истории и культуры Хэнаньского университета (Кайфэн)

e-mail: Ikshbaie@126.com

Кайфэн провинция Хэнань КНР ORCID0000-0001-8162-1906

DOI: 10.36340/2071-6818-2021-17-4-62-78

\section{ОБРАЗ КИТАЯ В КОРРЕСПОНДЕНЦИИ ЕКАТЕРИНЫ II}

Аннотачия: В 1762 году на российский престол восходит Екатерина II (1729-1796), Catherine le Grand как её называл Вольтер, необыкновенная женщина, которой суждено было проделать много реформ и утвердить место России в мировом пространстве. Время ее правления совпало с правлением императора Цяньлуна (1711-1799), одним из самых просвещенных монархов в истории Китая, при котором империя добилась Многих военных побед и блистательных достижений в искусстве. К моменту вступления Екатерины на трон отношения между двумя странами были очень натянуты. Между тем в Европе это был век Просвещения, век увлечения философией и искусством Китая. С одной стороны, Екатерина испытывала влияние идей Запада, с другой, - ей приходилось постоянно регулировать конфликты на российско-китайской границе, причиной которых чаще всего был вопрос о выдаче китайцам монголов и джунгаров, спасавшихся в пределах России. Цель данной статьивыяснить, какой образ Китая сложился у российской императрицы и как она отзывалась об этой стране в переписке с европейскими корреспондентами, ведь известно, что Екатерина II писала много. Для этого

Правление Екатерины II (1762-1796) совпало по времени с эпохой Просвещения в Европе и правлением императора Цяньлуна в Китае (1736-1795). Это правление было отмечено при нятием важных политических, законодательных и административных мер, достижениями в области науки, литературы и искусства, рядом военных торжеств, постоянным возрастанием народных сил и государственной славы России.

Известно, что в детстве Екатерина получила весьма ограниченное первоначальное образование. «Что делать? - Говорила она однажды.-Девица Кардель не могла выучить меня лучше. Она была старая француженка и образовала меня довольно, чтоб быть в замужестве за кем-нибудь из наших соседей» [2, C. XXIII]. Но, как Петр I и большая часть великих людей, Екатерина стремилас вначале необходимо дать характеристику личности императрицы, понять её интересы и привычки. Также нужно знать состояние российско-китайских отношений второй половины XVIII века, чтобы понять какие вопросы ей приходилось решать. И, наконец в статье даётся общая характеристика переписки Екатерины ІІ с разными высокопоставленными особами среди которых были Д'Аламбер, Дидро, Вольтер, франко-немецкий публицист Фридрих Мельхиор Гримм, швейцарский ученый и философ Иоанн Георг Циммерман, госпожа Жофрень и госпожа Бельке. Письма, получаемые ею, очень часто содержали дипломатические новости, династические проблемы, придворные сплетни, ответы её представляли из себя, большей частью, «официозныя журнальныя заметки». Привлекает внимание то, что несмотря на обширную переписку, которую вела Екатерина Велика она практически не касалась в ней вопросов Китая, исключение составили письма к Вольтеру, который как известно, восхищался Китаем и пытался больше узнать о нём от императрицы.

Ключевые слова: Китай, Екатерина II, Цяньлун, Просвещение, Вольтер, переписка.

к самосовершенствованию и вскоре восполнила недостатки в образовании, став в уровень с самыми просвещенными людьми своего века. После свадьбы она, по её словам, только и делала, что читала. «Никогда без книги и никогда без горя но всегда без развлечений», - так очерчивае Екатерина своё тогдашнее времяпровождение [7, С. 530]. Вскоре ей стали коротко известны труды современных и древних философов и политиков. Екатерина, полюбив всем сердцем вторую свою родину, изучила её язык, историю, быт её народа. Она внесла большой вклад в русскую историографию. «Наука русской истории начинается с Екатерины II» [2, C. VIII]. В её царствование были впервые напечатаны многие русские летописи, давшие возможность учёным взяться за составление российской истории. В ряду 
русских историков стоит и сама Екатерина. Ещё являясь Великой Княгиней, она ежедневно посвящала по несколько часов чтению истории, делая выписки и заметки, которые позже вошли в её «Записки касательно русской истории», появившиеся сначала в «Собеседнике», а потом вышедшие особым изданием. «Обнародование их в свете Императрица объясняет, с одной стороны, тем, что всякому народу знание своей собственной истории и географии нужнее, нежели посторонних, а с другой, что «оне сочинены для юношества в такое время, когда выходят на чу жестранных языках книги под именем истории Российской, кои скорее именовать можно сотворениями пристрастными, ибо каждый лист свидетельством служит, с какою ненавистью писан, каждое обстоятельство в превратном виде не токмо представлено, но к оным не стыдился прибавить злобные толки» [2, С. Х]. Это доказывает, Екатерина II оберегала честь России даже в области наук.

Являясь образованнейшей женщиной своего времени, императрица не могла пройти мимо идей Просвещения, среди которых была и идея о «просвещённом монархе». «Как и французские феодалы, Екатерина II и её придворные искали в образе жизни, законах, философии и истории Китая обоснование природы деспотической власти. <...> Недаром Екатерина особым указом по велела перевести Уголовное уложение Цинов, где прославлялось единоначалие правления и узаконивались привилегии маньчжурской знати» [14, C. 67]. «Екатерина читает "Essai sur les moeurs e esprit des nations, Le siècle de Louis XIV, Dictionnaire philosophique de la Chine". A пьеса "L'Orpheline de la Chine" («Китайский сирота», 1755) даже предполагалась к игре в придворном Эрмитажном театре - по аналогии с её постановкой перед Ки тайским павильоном в саду Сансуси в Потсдаме Специально по высочайшему повелению Алексей Леонтьев, один из первых европейских синологов, в 1770-х годах делает переводы с китайского языка. Причём большая часть их была осуществлена на «кошт Кабинета» [11, С. 73]. Интерес к Китаю в немалой степени подогревался общением с Вольтером, который восхищался Китаем и использовал китайский сюжет для острой философской полемики. Наиболее полно Вольтер высказался о Китае в «Опыте о нравах», «Философском словаре», «Бумагах Жана Неслье» и статье об «Изгнании иезуитов». «Вольтер замечает, что, если философ хочет говорить о событиях земного шара, он должен сначала бросить взоры на восток - «колыбель всех искусств, которой всецело обязан Запади [1, С. 317], Ека кер следует наставлениям Вольтера. Она не только изучает философию и литературу Китая, но и начинает собирать предметы китайского искусства. В Ораниенбауме появляется «Китайский дворец» в Царском селе - Китайские постройки, а в Зимнем Дворце - китайские комнаты.

Если говорить о внешней политике, прово димой Екатериной, то шаткость и переменчи вость, характерные для российской политики до её правления, уступили место решительным действиям. «Вместо дружбы со всеми державами она за 34 года своего правления перессорила Россию почти со всеми крупными государствами Западной Европы и внесла в нашу историю одно из самых кровопролитных царствований вела в Европе шесть войн и перед смертью готовилась к седмой - с революционной Франтовилась К седьмой
цией» $[7$, С. 563].

В соседнем Китае также не всё было спокой но. «С 1685 по 1792 год маньчжурские императоры вели 11 войн, продолжавшихся в общей сложности более 50 лет. С 1721 по 1795 год в Китае произошло 12 крупных восстаний, поднятых в основном национальными меньшинствами. Их подавление потребовало почти 30 лет. Внешние и внутренние военные действия зачастую протекали одновременно» [12, С. 145].

Придя к власти, Екатерина II с особым вниманием занялась урегулированием отношений с Ки таем. До середины 50-х годов XVIII века между Пекином и Петербургом сохранялись дружественные связи. Однако после завоевания Джунгарии бегства части ойратов, а затем и владетельного князя Ойратского ханства Амурсаны в русские пре делы, после перехода на русскую сторону населения отдельных монгольских княжеств, ситуация резко изменилась [12, С. 144]. Главною причиною возникавших затруднений был в основном вопрос о выдаче китайцам монголов и джунгаров спасавшихся в пределах России. Российское же правительство не могло сделаться сообщником жестоких наказаний, ожидавших перебежчиков в Китае. В результате китайское правительство не только не позволяло русским караванам пересекать границу, но даже строго запретило своим подданным поддерживать сношения с русскими $[10$, C. 28-29]
В 1762 году императрица отправила в Пекин капитана И. И. Кропотова с поручением известить императора Цяньлуна о её восшествии на престол и для урегулирования пограничных вопросов. «Руский посол был принят богдыханом, но с ним обошлись так сухо, что он не мог ничего добиться для восстановления торговли» [10, С. 30]

Отношения России с Китаем складывались непросто. Так, например, Ф. Ф. Мартенс, считает, что «с самого начала сношений России с Китаем китайцы имели к ней доверие; они всегда строго отличали русских от подданных других европейских государств, которых они называют иностранцами и даже "заморскими дьяволами"» [10, С. 2]. Но события показывали, что отношение к русским не всегда было доверительным. Причиной тому, по мнению Мартенса, было «несчастное последствие того обращения, которому подверглась Срединная империя со стороны других цивилизованных держав, и несправедливых войн веденных против нея» [10, С. 73]. Возникновению неурядиц способствовало и то, что в китайских сочинениях по географии о России упоминалось, как о государстве вассальном богдыхану $[10$, C. 7]. «Такой взгляд внушался богдыханам и отражался при приёме ими русских посланцев. Долгое время богдыханы искренне видели в них лишь по сланных от подвластнаго себе народа и требовали унизительных для русскаго достоинства поклонения и дани. Те из русских людей, присланных для установления торговых сношений с Китаем или по пограничным делам, которые не соглашались на унижения, не достигали и цели своей миссии» [8, С. 76]. Всё это не могло не отразиться на российско-китайской переписке. «Российская сторона, договорным образом подтверждая готовность переписываться с Лифаньюанем (Палатой по делам вассальных (!) территорий), как бы признавала себя "вассалом" Цинской империи. Однако, с другой стороны, с этим "назначением" отныне "снимались многие противоречия, возникавшие при переписке царей, следовательно, процесс достижения Россией своих целей облегчался"» $[9$, С. 107]

С 1763 года отношения между Россией и Китаем приняли ешё худший оборот, в 1764 году всякая официальная переписка с китайским правительством была прекращена, так как императрица Екатерина II не могла, не роняя своего достоинства, отвечать на дерзкие ноты «Лифаньюаня» $[10$, С. 30]. Обострившиеся отношения с китай цами заставили Екатерину в августе 1764 года составить в виду принятого китайцами «угрожающаго» положения чрезвычайную конференцию из князя Голицына, графов Панина, Чернышева, Миниха, Олсуфьева, Неплюева и Вильбоа, одним из намерений которой было отправить военную экспедицию к Амуру [15, С. 60]. В том же 1764 году она учредила комитет из компетентных лиц для изучения условий торговли с Китаем, по результатам работы которого было принято решение отменить казённую торговлю с Китаем и отдать её в руки русских купцов, а всё админи стративное управление Сибири преобразовать с целью улучшения отношений с Небесной империей [10, С. 29].

С 1762 по 1768 год торг беспрестанно прекращался и возобновлялся до тех пор, пок в 1768 году снова был послан капитан Кропотов в Кяхту для разрешения споров по пограничным и торговым делам. «После долгих прений, уполномоченные подписали, 18-го октября 1768 года, отдельный акт или дополнение к трактату 1727 года [10, С. 30]. С 1768 года после семи лет раздоров настали семь мирных лет - самый продолжительный мир начиная с 1719 года [15, С. 62]. Следующий разрыв отношений с китайцами произошёл в 1778 году (продолжался до 2 апреля 1780 года) по поводу некоторых Олотов, русских подданных разграбивших русских купцов и бежавших в Ки тай [15, С. 63]. В 1785 году произошёл новый раз рыв, продолжавшийся до 24 апреля 1792 года. На границе было поймано несколько разбойников русского подданства во главе с Уладзаем (Улагаем). Китайцы требовали их казни на месте преступления, а иркутский губернатор только сослал их. «Вследствие этого трибунал в 1785 году в листе своём жалуется, что губернатор своевольно только выбив палками Улагая и прочих, прежде шатавшихся, сослал их в отдалённую ссылку» $[15$ C. 63]

На фоне всех этих событий интересно было знать, как отзывалась российская императрица о Китае в своей переписке с иностранными корреспондентами, ведь, как известно, писала он много, и, как однажды заметила своему секретарю Грибовскому, «не пописавши нельзя и одного дня прожить» [2, C. XIII]. Причиной такой литературной активности было не только свойство её характера, но и влияние духа времени, когда было принято подражание великим умам того века. Отсюда берёт начало та обширная переписка, которую 
императрица вела сперва с Д'Аламбером, Дидро и Вольтером, потом с полунемцем-полуфранцузом Гриммом, затем с ганноверским учёным Циммерманом, с госпожой Жофрень (M-me Geoffrin) жившей в Париже и имевшей литературный салон, считавшийся литературным центром и верховным эстетическим судилищем, госпожой Бельке (M-me Bielke), которая в годы детства Екатерины была близка к её матери и жила в Гамбурге. «Эти сношения имели многообразную цель: с одной стороны, Екатерина желала таким способом быть постоянно в известиях обо всем, что происходило на западе и что о ней говорили; с другой, зная обширныя связи этих лиц, а также их авторитет и влияние на общественное мнение она желала своими письмами к ним распространять за границею верныя, или по крайней мере согласныя с ея видами, сведения о русских делах, опровергать клеветы и лживые толки, которые безпрестанно были распускаемы врагами России» [2, С. XIV]

«Письма, получаемые ею, очень часто содержали политическия сообщения, ответы её представляли из себя, большею частью официозныя журнальныя заметки: были здесь и бюллетени о походах, и воинствующие статьи, и, даже, «настоящие манифесты, как в письме от 21 января 1791 года, писанном к Циммерману, но предназначенном для берлинскаго двора, который надо было успокоить, давши ему в то же время совет не вмешиваться в турецкия дела. Многия из записок к Вольтеру имели целью поколебать положение герцога Шуазеля. Сама Екатерина однажды призналась в том Храповицкому» [5, С. 385-386].

При ознакомлении с её перепиской с разными особами, составившей пять томов, изданных Императорским русским историческим обществом, бросается в глаза то, как много она пишет о европейских делах и практически ничего об отношениях с Китаем, что, в общем, следует расценивать как положительное явление. Её корреспондентами, в разговоре с которыми она касается Китая, был Вольтер, а затем принц Шарль де Линь. Знакомство с произведениями Вольтера началось вскоре после её прибытия в Россию, когда она, по совету прусского посланника Мардефельда, отказалась от праздного препровождения времени и принялась за чтение $[2, \mathrm{C}$ XVI]. «С 1746 года, с того времени, как Я разполагаю Своим временем, Я чувствую ваше вели кое одолжение. Прежде сей эпохи Я не читал иных книг, кроме романов; но нечаянно попались Мне в руки ваши сочинения. С того времени они составляют Мое всегдашнее чтение и Я не искала иных книг как только таких котои А не искала иных кни, как толко таких котомного полезнаго» $[13$, С. 4-5], — пишет она в первом письме к Вольтеру.

В переписке Екатерины II с Вольтером, которая Алилась с 1763 по 1777 год - до смерти Вольтера, затрагивалось огромное количество вопросов о русской внутренней и внешней политике. Об этой переписке у польского историка К. Ф. Валишевского (1849-1935) есть интересные строки. «Она мечтала построить в Царском Фернейский дворец, воспроизведя вполне внешний и внутренний вид знаменитаго жилища, - комнату, где мыслил и писал философ, даже пейзаж, н котором покоился его взор. В то же время она ни за что не соглашалась опубликовать свою переписку с ним: ея письма были слишком дурно написаны, его - слишком лестны для нея и непочтительны для других властителей. И так как эта корреспонденция многими не одобрялась а слишком подозрительное высшее духовенство видело в ней почти что скандал, она начала просто отрицать её. Не могла же она запретить Вольтеру писать ей - столько людей ей писали! Но она не отвечала ему, она отклонила все попытки его вовлечь её в переписку, которая была бы недостойна императрицы всея Руси» [5, С. 213]

«В своих откровенных беседах с Гриммом "их тон очень заурядным"» [5, С. 391]. Это отнюдь не характеризует Екатерину как не мудрого правителя. Как уже было сказано, Екатерина была очень начитанна и во всём оберегала интересы России. «В приёме ею иностранных послов, в сношениях с кем бы то ни было, каждое слово, каждый шаг ея показывали необыкновенный такт и искусство безошибочно производит желанное впечатление. Екатерина была такой же тонкий дипломат, как и искусный администратор 2 С. XXIV]. Екатерина старалась следовать современной моде. «Мода же была относиться ко всему небрежно, иронически, вносить насмешку даже в обсуждение самых серьезных вопросов. Ко всему этому Вольтер приучил свою ученицу она в восторге от такого направления и применяет его и вкривь, и вкось, как женщина капри зная, смелая, мало обращающая внимание н правила и приличия» [5, С. 391]
Отношения между честолюбивой, политически могущественной женщиной и высокоодарённым, универсально образованным философом одним из крупнейших авторитетов французского Просвещения, были взаимовыгодными. Екатерина осознавала, что письма к Вольтеру станут известны его друзьям, и относилась к ним, как посланиям к интеллигенции Европы. «Для Вольтера, что могло быть ещё более лестным, чем иметь ещё одного королевского ученика в лице правящего монарха? Он обращался к ней как "Cемирамида Севера", "Святая Екатерина" и "Наша леди Санкт-Петербурга". В ответ она осыпала его соболиными мехами и табакерками с драгоценностями и посылала бриллианты Мадам Дэнис. Но это были отношения, которые процветали на расстоянии; несмотря на интимность их корреспонденции, Императрица и почтенный старец ни разу не встретились» [16, С. 335-336].

Как отмечает Валишевский, письма императрицы можно разделить на три категории: письма, писанные ею, сочинённые ею и напи санные по её заказу. Первые - наиболее редки [5, С. 386]. Письма к Вольтеру, на его взгляд почти все были написаны по заказу и являлись своего рода литературными произведениями «Пишу я собственноручно только к таким людям, которые, как я полагаю, любят меня, и которыми я дорожу; мне невозможно гоняться за остроумием, отборным изложением, - писала она герцогу де-Линю, - следовательно, я вовсе не для того пишу, чтобы это было напечатано, и ничто мне не кажется таким пошлым, как то что я написала, когда оно мне попадается в печати» [4, С. 96]. Она собственноручно списывала письма к фернейскому патриарху, сохраняя свойственную ей манеру писать: «известную фамильярность, игривое добродушие и искренность, даже оригинальность мысли и выражения», искусно обработанные поставщиками французской или русской прозы - Шуваловым, Козицким или Храповицким, по очереди служившими секретарями императрице [5, С. 387].

Как известно, Вольтер в своём сочинени «Опыты о нравах» первоначально, до прибав ления вводной части, начинал своё изложение всемирной истории с Востока - Китая, «где впервые зародилась цивилизация, в то время как Запад пребывал в полном варварстве» [6, С. 173-174]. В противоположность древнему Израилю и государствам нового времени, у Вольтера — это страна обретённой мудрости, справедливости и внутреннего мира. «Хотя китайцы не преуспели в науках но это первый в мире народ по морали и культурности (police). Это объясняется, по мнению Вольтера, тем, что во главе государства стоит мудрец - император, окруженный философами мандаринами. Они исповедуют конфуцианство, которое представляет чисто философскую рели кию - деизм. Народная масса, правда, коснеет в грубых религиозных предрассудках, но император и мандарины мудро используют удобные случаи, чтобы подрывать в народе грубые верования и культы. Отправляясь от сентиментальных, идеализированных описаний путешественников и миссионеров, Вольтер создал из китайской истории морализующую басню и поучение европейцам» [6, С. 174]. Естественно предположить, что, переписываясь с Екатериной, Вольтер не мог не осведомляться о соседе России - Китае, к которому он испытывал такой интерес.

Вначале философ пытается завести разговор относительно литературных талантов китайских императоров. Так, в письме от 26 мая 1767 года Вольтер пишет: «Сосед Ваш, Китайский Император, Камги, спрашивал одного Миссионера, можно ли на Европейских языках писать стихи? Он в этом сомневался» [13, С. 25]. Но Екатери на решила оставить без ответа это замечание. Через три года Вольтер в письме от 20 ноября 1770 года снова пытается затронуть тему Китая: «Вы имеете двух соседей, которые сочиняют стихи, а именно Король Прусской и Император Ки тайской; кои Фридрих уже сочинил Вам в похвалу, я имею и теперь ожидаю их от Киен-Лонга» [13, С. 133]. И снова не последовало ответа на эти строки. В следующем письме от 26 ноября Вольтер опять упоминает богдыхана: «Да здравствует Китайской Император! Он сочиняет стихи и с це лым светом живет в мире!» [13, С. 134] И снова молчание в ответ. В следующем письме от 22 декабря 1770 года Вольтер уже пишет с нетерпени ем: «Всемилостивейшая Государыня! Страсть мо становится несколько нещастною. Я не имею известия ни о Вашем Императорском Величестве ни о враге моем Мустафе. Все, что я могу еще сделать, состоит в том, чтоб сообщить Вам скуч ную мою переписку с Китайским Государем, Вашим соседом» [13, С. 140].

Как упоминалось выше, годы с 1762-го по 1770-й были наполнены решением многочисленных неурядиц, возникавших на российско-китай- 
ской границе, о которых Екатерина предпочитала не распространяться. И, наконец, в письме от 12/23 декабря 1770 года она заговорила о Китае: «Ах, Государь Мой! Вы так много расхвали ли Китай, что Я уже не смею не одобрить стихов, сочиненных Государем той страны. Однако же по делам, кои Я имею с сим Правительством, могла бы Я представить такия доказательства, которыя весьма уменьшили бы всеми принятое доброе мнение о их просвещенности, и заставили бы об них думать, как о грубых невежах; но на что обижать ближняго? Я, наложив на себя молчание, дивлюсь без всякаго противоречия присылаемым от находящихся там веропроповедников повествованиям. Сверх сего и то надобно сказать, что я имею дело с правлением Татар, овладевших Китаем, а не с природными Китайцами» [13, С. 143].

Затем, в следующем своём письме от 12/23 января 1771 года Екатерина продолжает: «Мне кажется, что вы можете быть довольны 1770 годом, и что не имеете еще причины соседом Моим, Ки тайским Государем, величаться, у которого Я, не смотря на его стихи и возродившуюся вашу к нему любовь (прошу не сердиться), не нахожу почти общаго смысла. Вы скажите, что одна ревность заставляет Меня там говорить; отнюдь нет; Я не поменяюсь Римским своим носом на плоское его лицо; не завидую также и дарованию его сочинять дурные стихи; Я люблю лишь одни ваши читать. Эпистола, писанная к Моему сопернику, прекрасна. Тотчас по получении показала ее Прусскому Принцу Генриху, и ему она равное принесла удовольствие. Естьли же судьбе угодно, чтоб Я, в разсуждении вас, имела совместни ка, то молю Пресвятую Богородицу Марию, чтоб это другой кто был, а не Китайской Государь; ибо Я на него сердита» [13, С. 148].

Затем, видно, в отношениях с Китаем наступает оттепель, так как императрица через два месяца пишет более мягко (письмо от 3/14 марта 1771 года): «С того времени, как сосед Мой, Ки тайской Государь, уничтожил некоторыя несправедливыя притеснения, то подданные его вступили с Моими в торговлю. В первые четыре месяца как сей торг открылся, променяли они товаров на три милиона рублей. Собственныя фабрики Моего соседа заняты деланием для меня обоев а сам он просит Меня доставить ему овец и хлеба» $[13$, C. 156]

В следующем письме (письмо от 5/15 марта 1771 года) Екатерина даёт более развёрнутую ха- рактеристику отношений с Китаем: «Вы желаете чтобы Я объявила вам нечто о невежестве и грубости Китайцев, о которых Мною упомянуто было в одном из моих писем. Мы соседи, это вам вестно границы наши с обеих сторон населяют Татары и идолопоклонники, скотоводством питающиеся. Сии народы чрезмерно склонны к грабе жу. Они похищают друг у друга (часто из одного мщения) стада и даже людей. Произшедшия от того ссоры прекращены посланными на грани цы Коммисарами. Господа Китайцы такие великие ябедники, что с ними самыя малости столько же трудно окончить, как море выпить. Неоднократно случалось, что они, будучи во всем уже удовлетворены, требовали костей после умерших не для того, чтобы оным какую честь воздать, но для того, чтоб над ними наругаться. Подобныя скаредности служили им в продолжении десяти лет предлогом к пресечению торговли; Я говорю предлогом по тому, что истинная причина была та, что его Китайское Величество торг с Россиею отдал одному из своих Министров в Монополию. Китайцы и Россияне были тем равно недовольны; а как очень трудно прервать всякой меновной торг, то оба народа производили мену своим товарам в тех местах, где не было учреждено таможенных застав, предпочитая свои нужды опасностям. А когда от нас им сообщено было подробное сведение о состоянии взаимного сношения, то в ответ получили мы от них превеликия кучи бумаг, написанных так беспорядочно, что вместо смыслу и вежливости, прочита их с начала до конца, видны были одне невеже ства и грубости. От нас им на это сказано было, что у нас такой слог совсем не годится, потому что он в Европе и Азии почитается оскорбительным. Я угадываю ваше возражение. Вы скажите что Татары, Китайским Государством овладевшие гораздо хуже древних Китайцев; согласна! Одна кож это останется неоспоримым, что победители не научились вежливости у побежденных, а сии напоследок принуждены будут покориться обычаям господствующим» [13, С. 160].

Это то немногое, что Императрица позволил себе сказать о Китае. Кроме обсуждения стихо императора Цяньлуна и торговых дел с Китаем ещё одной темой переписки становится возМожность посредством русских купцов сбывать в Китай часы, производимые фабрикой Вольтера. «Чтобы помочь людям в его деревне, он построил фабрику по производству часов и затем склонял всех своих друзей в Европе купить их продукцию; <...> К 1777 году эта когда-то маленькая, обнищалая деревня из 49 человек превратилась в процветающий городок из 1200 человек [16, C. 334]

Екатерина II не стала исключением - Вольтер обратился к ней с пространной речью, очень напоминавшей предложение разместить у него заказ. «Мне кажется, естьли бы Ваши Нипхские Татаро-Китайцы были догадливы, тоб могли они накупить недорогих часов и продавать их по своему Государству с великим барышем. Женевць имеют в Кантоне Контору, и получают там знатную прибыль. Не можно ли учредить таковой же и на Вашей границе? Колония моя наделала бы часов серебряных, ценою от 12 до 15, а золотых от 50 до 40 рублей. При том обязалась бь она в каждой год выставлять оных, ежели потребуется, на 200,000 рублей. Но мне кажется, что, по недоверчивости и подозрительности Китайцев, едва ли можно вступать с ними в большой торг, требующий сговорчивости и откровенности» $[13$, С. 167]

Императрица не ответила отказом, а приобрела часов на три-четыре тысячи рублей. Но Вольтер вскоре выслал ей вторую партию часов, поспешив извиниться: «Это случилось от слишком большого рвения "колонистов",- это не его, а их вина. Впрочем, счет составляет всего 39,238 француз ских ливров, это на половину дешевле, чем в Лондоне, Париже и даже Женеве. При уплате даются все льготы" - "Хорошо, отвечала Семирамида но это в последний раз". Она послала 39,238 ливров, вместе с бюллетенем о последних подвигах русских войск, о которых должен оповестить Европу человек, котораго наиболее читают во всем свете» [5, С. 202].

Далее в письме от 24 мая/4 июня 1771 года Екатерина выражает своё согласие на предложение о сбыте часов. «Я думаю, что была бы возможность доставлять их изделия в Китай; но для этого был бы нужен какой-нибудь образованный купец, который знал бы обычаи торговли с Кяхтой - пограничное с Россией место, где эта торговля производится. <... По моему повелению пересматривается таможенный тариф по торговле с Китаем с целью облегчить его, чтобы содействовать ввозу и вывозу. Цены, которыя вы назначаете, так умеренны, что изделия вашего производства могут иметь большой сбыт» [2, C. 103].
Вольтер, видимо, был воодушевлен этими строками, поскольку в одном из писем снова пытается предложить Екатерине часы, но уже настенные. Н что Екатерина в письме от 3/14 декабря 1771 года предложила обратиться «к какой-нибудь здешней конторе, где есть женевцы, которые легко найдут средство доставлять часы на китайскую границу» [2, С. 199].

Последнее письмо к Вольтеру было написано 4 декабря/23 ноября 1777 года, 30 мая 1778 года философа не стало. За 14 лет переписки Вольтер и Екатерина так и не встретились.

Больше Екатерина в своих письмах не касалас китайских дел, лишь иногда в переписке с принцем де-Линем, которая началась в 1781 году, она вскользь касалась китайского императора. Так в письме к принцу де Линю о воспоминании оставленном им о себе в России (11 июля 1782 г.), она писала: «Ни мой дорогой друг, Византийский Император, ни добрый мой сосед, Император Китайский не в силах помешать мне читать ваши письма, безконечно более приятныя, чем их письма, не смотря на их высокий ранг в альманахах [3, С. 210]. Или, как в письме о соседних с Россией государствах (16 ноября 1790 г.) она сообщала: «В пекинской газете сказано, что мой китайский сосед с маленькими глазками, о котором вы так почетно отзываетесь, соблюдает с истинно при мерной точностию все безчисленные обряды которым он подчинен» [4, С. 125]. Это то немногое что позво трица в переписке с принцем.

Подытоживая вышесказанное, можно сказать, что на взгляды Екатерины относительно Кита большое влияние оказал Вольтер, с произведениями которого она была хорошо знакома и переписку с которым вела в течение четырнадцати лет. Именно при Екатерине в русской периодике появляется большое количество переводных материалов на тему философии, государственного устройства и обычаев Китая. Но, читая бумаги, исходящие от китайского правительства, он осознавала, что всё то, чем восхищался Вольтер относилось скорее к древней китайской культу ре, носителем которой являлась национальность хань. Ей же приходилось иметь дело с захватив шими власть маньчжурами, пришедшими с северо-востока, обычаи и традиции которых несколько отличались. Обстановка на российско-китайской границе была неспокойной, торговые отношения с Китаем в царствование императрицы Екатери- 
ны II (1762-1796) прекращались три раза, а именно с 1762 года на шесть лет, с 1778 года на два, с 1785 года на семь лет. Было трудно вести переписку с китайским двором. И тем не менее императрица предпочитала не распространяться насчёт отношений с Китаем в письмах к своим многочисленным европейским корреспондентам, которые она писала практически каждый день. Исключение составили письма к Вольтеру, на за- мечания которого ей волей-неволей приходилось отвечать, и, которые, по мнению самой Екатерины, были дурно написаны. Эту сдержанность в переписке можно расценивать лишь как положительное явление, свидетельствующее о том, что Екатерина оберегала государственные интересы в отношении Китая, предпочитая не вмешивать западные государства в отношения со своим восточным соседом.

\section{БИБЛИОГРАФИЯ}

1. Алексеев М.П. Пушкин и мировая литература.Ленинград: «Наука», 1987.

2. Бумаги императрицы Екатерины II, хранящиеся в государственном архиве Министерства иностранных дел.- Т. 3. (1762-1774).- СПб.: Типография Императорской академии наук, 1874.

3. Бумаги императрицы Екатерины II, хранящиеся в государственном архиве Министерства иностранных дел.- Т. 4 (1774-1788); Сборник императорского русского исторического общества.- Т. 27.- СПб.: Типография Императорской академии наук, 1880.

4. Бумаги императрицы Екатерины II, хранящиеся в государственном архиве Министерства иностранных дел.- Т. 5 (1789-1796); Сборник императорского русского исторического общества.- Т. 42.- СПб.: Типография Императорской академии наук, 1885.

5. Валишевский К.Ф. Вокруг трона: Екатерина II.-М.: Сфинкс, 1911.

6. Вольтер: Статьи и материалы / Под ред. акад. В. П. Волгина; Акад. наук СССР.-Москва; Ленинград: 2-я тип. Издательства Академии наук СССР, 1948.

7. Ключевский В.О. Русская история. Полный курс лекций в 2-х книгах.- Книга 2 / Послесловие, комментарии А. Ф. Смирнова.-М.: ОЛМА-ПРЕСС, 2003.

8. Куропаткин А.Н. Русско-китайский вопрос.-СПб.: Тип. Товарищества А.С. Суворова «Новое Время», 1913.
9. Лапин П.А. Российско-китайская межгосударственная переписка как вид внешнеполитической деятельности: китайский аспект (первая половина XVIIвторая половина XIXв.) // Россия и Китай: проблемы стратегического взаимодействия: сборник Восточного центра. - 2012. — № 12.—C. 106-114.

10. Мартенс Ф. Ф. Россия и Китай.-СПб.: Тип. И. Габермана, 1881.

11. Меньшикова М. Здесь «все дышало амброзией Азии» // Воображаемый Восток: Китай «по-русски». XVIII - начало XX века / Сост. О. А. Соснина.— М.: Кучково поле, 2016.-С. 66-73.

12. Непомнин О.Е. История Китая: Эпоха Цин. XVIII начало XX века.- М.: Восточная литература, 2005.

13. Переписка российской императрицы Екатерины II и господина Вольтера, продолжавшаяся с 1763 по 1778 год / Перевел с французского Иван Фабиян; С портретом императрицы и Вольтера.-М.: В вольной типографии Гария и Компании, 1803.

14. Скачков П.Е. Очерки истории русского китаеведения.-М.: Издательство «Наука», Главная редакция восточной литературы, 1977.

15. Трусевич X. Посольские и торговые сношения России с Китаем (до XIX века).- М.: Типография Г. Малинского, 1882.

16. Robert K. Massie. Catherine the Grate: Portrait of a Woman.- New York: Random House Trade Paperbacks, 2012. 